\title{
The Influence of Food Quality and Price Fairness on Customer Satisfaction and Repurchase Intention at Manangkabau Satay Restaurant in Padang, Indonesia
}

\author{
Muhammad Ikhsan Nazulis ${ }^{1} \quad$ Syafrizal $^{2 *}$ \\ 1.Master of Management, Faculty of Economics and Business, Andalas University, Padang, Indonesia \\ 2.Department of Management, Faculty of Economics and Business, Andalas University, Padang, Indonesia
}

\begin{abstract}
This study aims to determine "The effect of Food Quality and Price Fairness on Customer Satisfaction and Repurchase Intention of Customer at satay restaurant in Padang City". The survey technique was applied to 125 satay customers in Padang, West Sumatra, indonesia. Research instrument were adapted from previous studies. The data of this study were analyzed by using structural equation modelling (SEM) technique with Smart Partial Least Square (SmartPLS 3.0) application. The results of this study indicate that Food Quality has significant effect to customer satisfaction and repurchase intention. In addition, Price Fairness also has significant effect to repurchase intention. Meanwhile, Price Fairness does not have significant effect to customer satisfaction. Furthermore, Customer Satisfaction has significant effect to repurchase intention.
\end{abstract}

Keywords: Food Quality, Price Fairness, Consumer Satisfaction, Repurchase Intention

DOI: $10.7176 / \mathrm{EJBM} / 13-14-08$

Publication date:July $31^{\text {st }} 2021$

\section{Introduction}

Indonesia is a country that has a variety of cultures and typical foods in each region. One of the businesses that are often encountered is the culinary business. Indonesian culinary has proven to have a great appeal, especially with the crowning of rendang which is a traditional West Sumatra culinary delicacy as one of the most delicious foods in the world (CNN, 2017).

Apart from rendang in the first place and fried rice in the second place, Indonesia also has the most delicious food in the world, namely satay. Sate is food served with herbs and a wide range of complementary meat such as beef, meat goat, meat chicken, offal is pricked and seasoned before being burned. The satay culinary destination is also included in the list of the most delicious food which is ranked 14th out of the 50 most delicious food category in the world based on the voting conducted by CNN in 2017 through 35,000 Votes on CNN Facebook Media (CNN, 2017)

Sate Padang is very interesting to be developed as one of the culinary icons from West Sumatra. In addition to developing the economic development of the workforce who are engaged in this satay trade, whose status is still informal and of course will also strengthen the cultural character of West Sumatra.

The rapid development of the culinary business in West Sumatra has made satay traders also participate in preserving this food in West Sumatra, especially in the city of Padang. Lots of small industries that produce satay products. This satay is different from the type of satay. This of course will also strengthen the cultural character of West Sumatra which not only has special food but is also able to compete

Sate Manangkabau is a brand that elevates the taste of Minang cuisine to a higher level as a dish that is the result of the Minangkabau culture that is suitable for consumption by local people and tourists. Sate Man an gkabau was founded by Omar Rofil and Niwa Hidayah with a standard equivalent to a restaurant.

The concept of Sate Manangkabau, namely as the first Sate Padang restaurant in West Sumatra, which serves three color variants of satay at once, which have different taste and character as a symbol of marawa color (symbol of West Sumatra) in Minangkabau culture, such as yellow satay, red sate broth, and sate kuah. peanuts. In the last few months, Sate Manangkabau has received a lot of media coverage as an innovator in West Sumatra culinary (Prima, October 2019).

In addition, the innovation of typical Minang food also received direct support from the Padang City government together with the Mayor of Padang Mahyeldi who also participated in the inauguration of the launching of Sate Man an gkabau on May 4, 2019. This was done as the government's appreciation for Minang entrepreneurs, especially young and be creative with the aim of being able to contribute to the addition of culinary tourism destinations in the city of Padang (BentengSumbar, 2019).

Not just satay, these Minang specialties also offer satay food combined with a restaurant atmosphere that adds value to the place. So that it is suitable to be a hangout, meeting, or even a place for a culinary tour with family and coworkers, the success of Sate Manangkabau certainly cannot be separated from the Food Quality, Price Fairness and Perceived Value offered, causing Consumer Satisfaction to consumers, and influencing Repurchase Intention after visited Sate Manangkabau. 
Apart from Prince Fainess, several studies have proven that, Qin and Prybutok (, 2010) in the restaurant industry, Food Quality is the most important influence on customer behavior. Food Quality is a fundamental aspect of restaurant success. More specifically, Food Quality is a prerequisite when customers choose a restaurant. Similar findings by Aidin Namin (2017) show that Food Quality has a positive and significant effect on Consumer Satisfaction and Repurchase Intention, Apart from perceived Value, other variables affect competitive advantage. is Price fairness, Price fairness is the view and comparison between the reference price perceived by the buyer and the actual price of the seller El Hadad et al (2016)

Based on the data above, it can be concluded that some of the people of Padang City like Manangkabau satay because of its taste, spices, and comfortable place, complete choices, strategic location, so that the evaluation was carried out regarding the experience in a visit to Manangkabau Sate, the perceived value and satisfaction. the visitor as a whole influences future behavior in consideration of the desire to return to the same destination and his willingness to recommend it to others

Based on the description above, Sate Manangkabau in Padang City is a local restaurant with a combination of typical Minang food and modern concepts (Prima, October 2019). In the midst of fierce competition, Sate Manangkabau is able to innovate even though it is still relatively new. Therefore, researchers are interested in conducting research in the form of a thesis entitled:

The Influence of Food Quality and Price Fairness on Customer Satisfaction and Repurchase Intention at Manangkabau Satay Restaurant in Padang, Indonesia.

\section{Literature Review}

\subsection{Repurchase Intention}

Repurchase Intention is very important for business practitioners because it is an indication of business continuity, prospects for future income generation and hence business profitability (Trivedi 2019). Therefore, both business practitioners and academics are equally interested in identifying Repurchase Intention then Theodoraki (2009) Repurchase Intention is basically customer behavior where customers respond positively to the quality of service of a company and intend to make return visits or re-consume the company's products.

Meanwhile, according to Mowen and Minor (2016), it means that customers buy repeatedly for certain products or services. From some of the references above, it can be concluded that Repurchase Intention is a desire that arises in a customer to repurchase a product or service in the future after having previously consumed the same product or service.

Repurchase Intention is the intention to repurchase a product twice or more, for the same or different products (Zeng et al, 2009). Repurchase interest refers to the possibility of using the same service provider in the future. This is a consumer behavior that measures the tendency to continue, increase, or decrease the number of services provided by the current service provider. Repurchase interest measures are usually obtained from customer surveys when assessing the propensity of consumers to buy the same brand, the same product or service, from the same company (Noyan and Simset, 2019).

From some of the descriptions above, in general it can be concluded that repurchase intention is a tendency for someone to act and behave towards objects that attract attention accompanied by feelings of pleasure in the form.According to Dabholkar et al. (2014) The intention to repurchase is an assessment of repurchase at the same company based on experience using previous products / services. The desire to repurchase is related to an assessment of the same company in meeting its needs (Zeng et al, 2009).

\subsection{Repurchase Intent ion indicator}

According to Theodoraki et al, (2019) Repurchase Intention can be identified by several indicators, namely:

1. Reference is someone to refer to other people.

2. Explorative, namely someone looking for information on the product he wants.

3. Transactional that is, the current tendency to buy a product.

4. Preferential, describes the behavior of someone who has a major preference for the product.

According to Trivedi and Yadat (2019), identifying Repurchase Intention can be through the following indicators; 1) Buyback, which is to buy back from the same online market 2) Buy back in the future 3) Preferential interest, which is an interest that describes the behavior of someone who has a major preference for the product. This preference can only be changed if something happens with the preference product. 4) Exploratory interest, this interest describes the behavior of a person who is always looking for information about the product he is interested in and looking for information to support the positive properties of the product and its various variants. Nigam (2012) states that the indicators used are re-purchase interest, purchase between 1 to 3 months and after re-purchase .

\subsection{Food Quality}

According to Konuk (2019) and Ryu et al. (2012) Food Quality is described briefly as food that is well 
presented, fresh and delicious. Namkung and Jang (2008: 149) identify the presentation and taste of food as the most influential Food Quality factors. Research by Ha and Jang (2012), Ryu and Han (2010), and Ryu et al., (2012) further shows that customer perceptions of food quality in restaurants spread to other consumers about the positives of restaurants through word-of-mouth.

According to Ryu et al, (2012) "Food Quality is the most important attribute of the overall quality of restaurant service and is expected to have a positive relationship with customer satisfaction and loyalty. If a restaurant is able to provide good service for its customers, it will be able to create customer satisfaction and loyalty, besides that customers will come back to the restaurant. Furthermore, according to Namkung and Jang (2007); Sulek and Hensley (2004) Food Quality is one of the most important components of the dining experience. Clark and Wood (1999) in Ha and Jang (2010) emphasized that Food Quality is the main factor affecting customer loyalty in restaurants. Susskind and Chan (2000) in Ha and Jang (2010) insist that from a customer perspective, Food Quality is a key determinant for visiting a restaurant .

\subsection{Factors Affecting Food Quality}

In serving food in a good form, one must pay attention to several factors of quality of food. According to Gregorius (2011) in his book Service, Quality \& Satisfaction, states that there are several factors that affect Food Quality, namely as follows:

1. Color

The colors of the ingredients should be combined in such a way that they don't look pale or they don't match. The color combination is very helpful in the consumer's appetite.

2. Appearance

Expression - looks good enough to eatll is not an exaggeration. Food should be well viewed on the plate, which is an important factor. The freshness and cleanliness of the food served is an important example that will affect the appearance of food whether it is good or not to be enjoyed.

3. Texture

There are many textures of food including smooth or not, liquid or solid, hard or soft, dry or moist. The thin and fine levels and shape of food can be felt through the pressure and movement of the receptors in the mouth.

4. Taste

The taste point of the tongue is the ability to detect the basics, namely sweet, sour, salty, bitter. In certain foods, these four flavors are combined to form one unique and interesting taste to be enjoyed.

In the restaurant industry, Food Quality is the most important influence on customer behavior (Sulek and Hensley, 2004). Researchers (eg, Kivela, 1999; Sulek and Hensley, 2004) have determined this attribute is a determinant of consumer satisfaction in the restaurant industry. Liu and Jang (2009) suggest that food quality, environmental cleanliness, and service reliability are three fundamental aspects of restaurant success. More specifically, Food Quality is a prerequisite when a customer selects a restaurant. Ha and Jang (2010) show that food quality has a positive and significant effect on consumer satisfaction and loyalty. Qin and Prybutok (2009) conducted a study by revealing that the general explanation of Food Quality focuses on variety, cooking methods, presentation, and freshness.

1. Variation, involving the number or scale of different menu items.

2. How to cook, involves how the restaurant cooks the food to be served.

3. Presentation, refers to how attractive food is presented and decorated as a tangible cue to the customer's perception of quality.

4. Freshness, usually refers to the posture of fresh food and seems to be associated with crispness and aroma

\subsection{Fairness Concept}

The concept of fairness is closely related to the concept of marketing, because in this concept the goal is to achieve the same results as the goal for which marketing is carried out, namely to achieve sales results. Bolton et al. (2003) defines fairness as a consideration of whether a result and / or a process to achieve that result is reasonable, acceptable, and appropriate. It can be said that fairness is an effort so that what is done is reasonable, the truth can be accepted, which means fairness is related to the creation of a fairness.

Fairness as a whole talks about appropriateness, fairness and fairness, meaning that all people have the right to equal rights equally and fairly. In simple terms, fairness can be defined as fair and equal treatment in fulfilling stakeholder rights that arise based on agreements and applicable regulations.

Fairness is expected to make all company assets managed properly and prudently, so that the protection of the interests of shareholders is fair (honest and fair). Fairness is also expected to provide protection to companies against harmful corporate practices as mentioned above. In short, fairness is the soul to monitor and ensure fair treatment among various interests in the company.

However, like a principle, fairness requires conditions to be enforced effectively. These requirements are 
in the form of clear, firm, consistent and enforceable rules properly and effectively. Theoretically, "fairness has roots in the theory of justice or a theory of justice adapted from the theory of equity and social exchange ( Worthington \& Devlin, 2013, p. 291).

\subsection{Factors affecting Price Fairness}

Basically, the determination of a fair price or price fairness is influenced by various aspects both from the company itself and from the company's market share where the company will emphasize prices that are deemed reasonable or low prices so that consumers feel the benefits of the products and services received are very useful as the theory suggests. stated by Kotler \& Keller (2016) as follows. Some companies want to maximize their market share. They believe higher sales volume will lead to lower unit costs and higher long-term profits, so they set the lowest price, assuming the market is price sensitive. Companies will build large factories, set the lowest possible price, win a large market share, experience cost reduction, and cut prices further as costs fall.

Research conducted by Celil (2019) found that there are two factors that affect price fairness, namely aspects of consumer insight and experience, insight is how a person knows a subject matter from what they know either from theory or practice directly, Consumers make reference prices choosing -choosing prices through the insights that consumers have, besides that the experience of consumers about what they have bought will result in perceptions of the products and services that consumers have previously received, this perception will be a driver for consumers to compare a price that is considered reasonable. "A person's level of insight about prices, costs and profits can contribute to the perception of the unfairness of a price (Ahmat et al, 2016).

Experience will shape the consumer's memory of what they have paid for and they got. " Consumers provide assumptions, subjective interpretations, conclusions based on past experiences, or hasty judgments" Ahmat et al. (2016,). "Experience generally consists of insights or abilities or investigations about something obtained after being involved or after exploring something (Ahmat et al, 2011).

Price fairness forming factors can be influenced by cognitive attributes and price comparisons and can impact favorable interest behavior (loyal behavior and willingness to pay more, or undesirable behavior (complaints and bad treatment) through unfavorable emotional responses.

From the definitions of price fairness above, it can be concluded that price fairness is the view or perception of consumers on prices that are considered reasonable and have high benefits with the products and services that consumers get, in some of the definitions above the writer uses the theory of Consuegra et al. (in El Hadad et al, 2016) which states that Price fairness is the view and comparison between the reference price perceived by the buyer and the actual price of the seller.

\subsection{Consumer Satisfaction}

Satisfaction (Satisfaction) is the feeling of happy or disappointed someone who appears after comparing the performance (results) of the product thought against the expected performance (or results). If the performance is below expectations then the customer is dissatisfied. If performance exceeds expectations, the customer is very satisfied or happy (Kotler \& Keller, 2016). So, satisfaction is a function of perceptions or impressions of performance and expectations. If the performance is below expectations, the customer is not satisfied. If the performance meets expectations, the customer will be satisfied. If the performance exceeds expectations, the customer will be very satisfied or happy.

According to Lovelock and Wirtz ( 2011) "Satisfaction is an attitude that is decided based on the experience gained. Satisfaction is an assessment of the characteristics or features of a product or service, or the product itself, which provides a level of consumer pleasure related to meeting consumer consumption needs. Customer satisfaction can be created through quality, service and value. The key to generating customer loyalty is providing high customer value.

According to Kotler and Armstrong (2012), customer value is the comparison of customers between all profits and all costs that must be incurred to receive a given offer. Total customer costs are a group of costs that are used in assessing, obtaining and using a product or service. Because Consumer Satisfaction is very dependent on customer perceptions and expectations, as a product supplier it is necessary to know the factors that influence it.

According to Zeithaml (2003) there are four factors that influence customer perceptions and expectations, namely as follows:

1. What customers have heard from other customers (word ofmouth communication).

Where this is a potential factor that determines the customer's expectations. For example, a customer owns a company that is expected to provide high quality service based on recommendations from friends or neighbors.

2. Customer expectations are highly dependent on individual characteristics where personal needs (personnel needs).

3. The experience of the past (past experience) in using the service can also affect the level of customer expectations. 
4. Communication with external parties (external communication) from service providers plays a key role in shaping customer expectations. Based on External communication, the service provider company can provide messages directly or indirectly to its customers. An example of the effect of external communication is the price at which service costs play an important role in shaping customer expectations.

\subsection{Hypothesis Development}

\subsubsection{The Effect of Food Quality to Consumer Satisfaction and Repurcahse Intention}

According to Ryu et al. (2012) food quality atributs are the most important attribute among total service quality in the restaurand and have significant effect to customer satisfaction and loyalty. When the restaurant able to provide good service quality to the customer, it will improve their satisfaction and loyalty to the restaurant. Previous researchs have emphasize the important of food quality to enhance customer satisfaction and loyalty (Konuk 2019; Prybutok 2010; Jalilvand 2017; Hyun 2010). For example study of Konuk (2019) at restaurant industry in Istanbul, Turkey found that food quality has significant effect on customer satisfaction and loyalty. Some researcher have interest to test the effect dimensions of food quality to customer satisfaction and loyalty. For example, study of Qin and Prybutok (2010) at restaurant industry found that dimensions of food quality such as food variaty, the way of cooking, food presentation and the freshness of food have significant effect to customer satisfaction and loyalty. Based on these previous researchs, the next hypothesis is proposed.

Hypothesis 1: Food Quality has significant influence on customer satisfaction.

Hypothesis 2: Food Quality has significant influence on repurchase intention.

\subsubsection{The Effect of Price Fairness to Consumer Satisfaction and Repurchase Intention}

Price fairness is refers to customer comparison whether the difference of price from competitor and price they paid for certain product or serveces is make sense or notPrice fairness related to price decision strategy since customer will compare money they spent with value (benefit) they get from purchase goods or services (Konuk 2019). When customer perceived received higher value, it will encourage customer to do repeat purchase and to recommend products or services to others (Wang and Leou 2015). In other words, higher customer value will lead to customer satisfaction and loyalty (Pike and Bianchi 2013). Therefore it is important for managers to enhance customer perceived value through delivering higher benefit og goods and services that exceed money spent by customer (Milfener 2009). Previous researchs found that price fairness has significant effect on customer satisfaction and Loyalty (repurchase intention) (Konuk, 2019; Bo et al. 2017; Chung 2010; El Hadadat et al. 2015 and Lee 2011). Based on these previous researchs finding, the next hypothesis are proposed.

Hypothesis 3: Price fairness has significant influence on customer satisfaction. Hypothesis 4: Price fairness has significant influence on repurchase intention.

\subsubsection{The Effect of Consumer Satisfaction to Repurchase Intention}

According to Lovelock and Wirtz (2011) customers satisfaction is customer attitude or feeling of happiness resulted from their consumption experience that fulfill or exceed their expectation. Customer satisfaction can be improved through enhancing product and service quality as well as customer value. Higher customer value will induce customer positive experience and satisfaction that in turn enhance customer loyalty (repurchase intention) (Milfelner 2009). Previous reserachs found that customer satisfaction has significant effect on customer loyalty (repurchase intention) (Konuk, 2019; Bo et al. 2017; Chung 2010; El Hadadat et al. 2015 and Lee 2011). Based on the previous research finding, the next hypothesis is proposed.

H5. Customer Satisfaction has significant effect on Customer Loyalty

\section{Research methods}

This study uses a quantitative method with the unit of analysis being individual customers. The study population was the customer who visit satay restaurant in Padang, West Sumatra, Indonesia. Convenience sampling technique was used in collecting research data. The survey was applied on 125 research respondents in West Sumatera. According to Hair et al. (2010) the number of research respondent as much as 5 to 10 time of research indicator is regarded sufficient for the research that used multivariate statistical for data analysis. In this study, there are 25 research indicators. Therefore total sample in this study is 125 respondent $(5 \times 25$ indicators). The research instruments were adapted from previous literatures. Variable of food quality, price fairness and customer satisfaction were adapted from Konuk (2019). Meanwhile, repurchase intention was adapted from Chen (2014). The research indicators were measured by using five point Likert scale. The research data were analyzed using structural equation modeling techniques with software SmartPLS 3.0.

\section{Research Finding 4.1 Respondent Profile}

As many as 84 people (51.2\%) of respondents graduated from senior high school and below, as many as 50 people $(40 \%)$ of respondents have bachelor degree (Diploma and $\mathrm{S} 1)$ and the rest as many as 11 people $(8.8 \%)$ of respondent have postgraduate degree. Based on gender, as many as 68 people $(54,4 \%)$ of respoden are male 
and 57 people $(45,6 \%)$ of respondents are female. Based on the age as many as 69 people $(55.2 \%)$ of respondent are between 21-35 years old, as many as 29 people (23,2\%) of respondent below 20 years old and as many as 27 people $(21.6 \%)$ of respondents are above 36 yeras old. Based on the job, as many as 22 people $(17.6 \%)$ of respondents are state owned entreprise employee, public servant, police and army; as many as 62 people (49.6\%) of respondents are college student; and the rest as many as 41 people $(32.8 \%)$ of respondent are entrepreneur, private employee and farmer.

\subsection{Measurement Model}

Analysis of measurement model in this research aims to check reliability and validity of research instrument. The assesment of loading factor and composite reliability are conducted to check reliability of research instrument. Then, the assesment of convergent validity and discriminant validity were conducted to check construct validity. According to Hair's et al. (2016), a research instrument has good reliability when the score of Cronbach Alpha and Composite Reliability are 0.7 or higher. Table 1 shows that both of Cronbach Alpha and Composite Reliability have score more than 0.7 . Therefore, it implies that this research instrument has good reliability.

A research construct is said has high validity when it has average variance extracted (AVE) score 0.5 or above (Hair et al. 2016). Table 1 shows that the score of AVE is higher than 0.5. Therefore, it indicates that this research instrument has good construct validity.

Table 1: Summary of Measurement Model

\begin{tabular}{|l|l|l|l|l|l|l|}
\hline Research Variable & $\begin{array}{l}\text { Measurement } \\
\text { Item }\end{array}$ & $\begin{array}{l}\text { Cronbach } \\
\text { Alpha }\end{array}$ & $\begin{array}{l}\text { Factor } \\
\text { Loading }\end{array}$ & CR & AVE & $\mathbf{R}^{2}$ \\
\hline Fq (food quality) & Fq1 & & 0.840 & 0.858 & 0.603 & \\
\hline & Fq2 & & 0.713 & & & \\
\hline & Fq3 & & 0.753 & & & \\
\hline & Fq4 & & 0.796 & & & \\
\hline PF (Price Fairness) & PF1 & & 0.814 & 0.776 & 0.538 & \\
\hline & PF2 & & 0.661 & & & \\
\hline & PF3 & & 0.717 & & & \\
\hline CS (Customer Satisfaction) & CS1 & & 0.828 & 0.885 & 0.720 & 0.320 \\
\hline & CS2 & & 0.838 & & \\
\hline & CS3 & & 0.906 & & & \\
\hline RI (Repurchase Intention) & RI1 & & 0.703 & 0.909 & 0.716 & 0.667 \\
\hline & RI2 & & 0.870 & & & \\
\hline & RI3 & & & & \\
\hline
\end{tabular}

Note: $\mathrm{FQ}=$ food quality; $\mathrm{PF}=$ Price Fairness; $\mathrm{CS}=$ Customer Satisfaction;

$\mathrm{RI}=$ Repurchase Intention, $\mathrm{AVE}=$ average variance extracted; $\mathrm{CR}=$ composite reliability

Discriminant validity of the research constructs was assesed by using Forner and Larcker's criterion was used in this study. A research construct has good discriminant validity when the square root score of AVE exceed the correlation of all the other constructs in correlation matrix (Hair et al., 2016). Table 2 shows that square roots of AVE were higher than other correlation among constructs. The Forner and Larcker result indicate that the discriminant validity of construct in was good.

Table 2: Correlation Matrix of Constructs

\begin{tabular}{|l|r|r|r|r|}
\hline & \multicolumn{1}{|l|}{ FQ } & \multicolumn{1}{l|}{ PF } & \multicolumn{1}{l|}{ RI } & \multicolumn{1}{l|}{ STS } \\
\hline FQ & 0.777 & & & \\
\hline PF & 0.389 & 0.733 & & \\
\hline RI & 0.683 & 0.421 & 0.846 & \\
\hline STS & 0.557 & 0.308 & 0.739 & 0.849 \\
\hline
\end{tabular}

Note: $\mathrm{FQ}=$ functional quality; $\mathrm{PF}=$ price fairness;

$\mathrm{STS}=$ satisfaction; $\mathrm{RI}=$ repurchase intention 


\subsection{Structural Model, Hypothesis Testing and Results}

Table 3: Summary of Structural Model

\begin{tabular}{|c|c|c|c|c|c|}
\hline & $\begin{array}{l}\text { Origina } \\
\text { I } \\
\text { Sample } \\
\text { (O) }\end{array}$ & $\begin{array}{l}\text { Sampl } \\
\text { e } \\
\text { Mean } \\
\text { (M) }\end{array}$ & $\begin{array}{l}\text { Standar } \\
\text { d } \\
\text { Deviatio } \\
\text { n } \\
\text { (STDEV } \\
\text { ) }\end{array}$ & $\begin{array}{l}\text { T Statistics } \\
\text { (|O/STDEV| } \\
)\end{array}$ & $\begin{array}{l}\mathbf{P} \\
\text { Values }\end{array}$ \\
\hline H1. Food Quality -> Consumer Satisfaction & 0.516 & 0.513 & 0.078 & 6.591 & 0.000 \\
\hline H2. Food Quality -> Repurchase Intention & 0.352 & 0.353 & 0.081 & 4.330 & 0.000 \\
\hline H3. Price Fairness -> Consumer Satisfaction & 0.107 & 0.117 & 0.082 & 1.309 & 0.191 \\
\hline H4. Price Fairness-> Repurchase Intention & 0.129 & 0.131 & 0.048 & 2.695 & 0.007 \\
\hline $\begin{array}{l}\text { H5. Consumer Satisfaction } \rightarrow \text { Repurchase } \\
\text { Intention }\end{array}$ & 0.504 & 0.499 & 0.081 & 6.229 & 0.000 \\
\hline
\end{tabular}

Table 2 show that coofficient determinant $\left(\mathrm{R}^{2}\right)$ of customer satisfaction is 0.320 . It means that as much as $32 . \%$ variance in customer satisfaction is explained by food quality and price fairness (refer Table 1). Further investigation on regression coofficient of FQ-STS finds $\beta=0.516(\mathrm{t}=6,591 ; \mathrm{p}$-value $<0.000)$ and regression coofficient of FQ-RI finds $\beta=0.352(t=4,330 ; p$-value $<0.000)$. From these $\mathrm{R}^{2}$ and $\beta$ values, It can be concluded that hypothesis H1 (food quality has significant effect to customer satisfaction) and $\mathrm{H} 2$ (food quality has significant effect to repurchase intention) are supported.

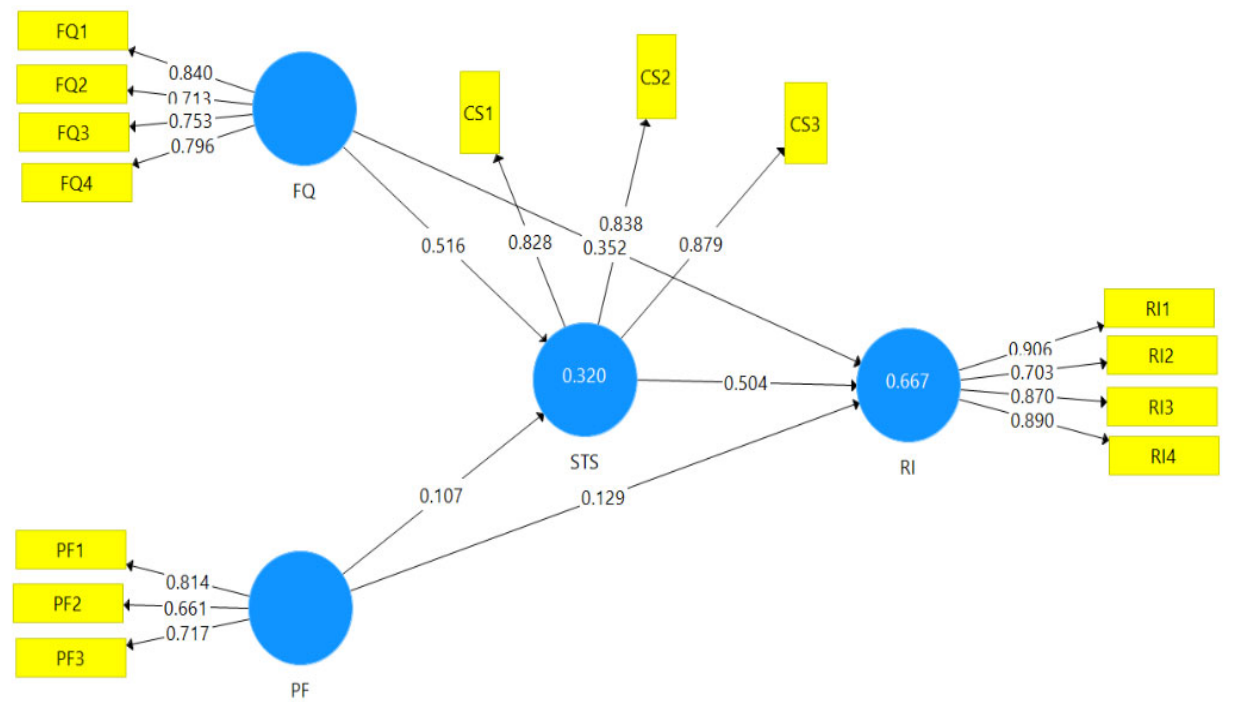

Figure 1. The relationship of theoritical model for the analysis of structural model

In addition, Table 2 show that coofficient determinant $\left(\mathrm{R}^{2}\right)$ of repurchase intention is 0.667 . It means that as much as $66,7 \%$ variance in repurchase intention is explained by food quality, price fairness and customer satisfaction (refer Table 1). Further investigation on regression coofficient of PF-STS finds $\beta=0.107(t=1.309 ; p-$ value $<0.191$ ) (refer Table 3 ) and on regression coofficient of PF-RI finds $\beta=0.129(t=2,695$; $p$-value $<0.007)$ and on regression coofficient of STS-RI finds $\beta=0.504\left(\mathrm{t}=6,229 ; \mathrm{p}\right.$-value $<0.000$ (refer Table 3 ). From these $\mathrm{R}^{2}$ and $\beta$ values, it can be concluded that both hypothesis $\mathrm{H} 3$ (price fairness has significant effect to customer satisfaction) is rejected. Meanwhile, hypothesis H4 (price fairness has significant effect to repurchase intention) and H5 (customer satisfaction has significant effect on repurchase intention) are supported

\subsection{Discussion}

\subsubsection{The link of Food Quality and Satisfaction}

This study found that food quality has significant effect to customer satisfaction. It means that the increase of food quality will increase customer satisfaction. When customer come to satay restaurant, they expect will consume nice taste, hygienese, nice smell, fresh and well cooke satay. When restaurant can meet or exceed these expectation then customer will satisfy. Therefore, it is very important for restaurant to keep and improved food quality continously in order to improve customer satisfaction. This finding inline with previous research that found that food quality has significant effect to customer satisfaction (Konuk 2019; Prybutok 2010; Jalilvand 2017; Hyun 2010). 


\subsubsection{The link of Food Quality and Repurchase Intention.}

This study found that food quality has significant effect to repurchase intention. It means that the increase of food quality will increase customer repurcahse intetion. After consuming nice taste, hygienese, and fresh satay customer will have positive experience and feel satisfy to the food. Customer positive experience and satisfaction will motivate them come again to the restaurant in the future when they want to eat satay. Therefore, it is very important for restaurant to keep and improved food quality continously in order to improve customer repurcahse intention. This finding inline with previous research that found that food quality has significant effect to customer repurchase intention (Konuk 2019; Prybutok 2010; Jalilvand 2017; Hyun 2010)

\subsubsection{The link of Price Fairness and Satisfaction}

This study found that food quality does not have significant effect to customer satisfaction. It means that the increase of perceived price fairness is not be able to increase customer satisfaction significantly. The posible justification for this finding is because currently customer have perceived high price fairness to the restaurant. In other words, customer have perceived that they have paid reasonable price for the food they have consumed. It means that food price that have been paid by customer have meet or exceed their expectation. Therefore, the increase of price fairness will not increase customer satisfaction significatly. This finding is different with previous researchs that found that price fairness have significant effect to customer satisfaction (Konuk, 2019; Bo et al. 2017; Chung 2010; El Hadadat et al. 2015 and Lee 2011)

\subsubsection{Price Fairness and Repurchase Intention}

This study found that price fairness has significant effect to repurchase intention. It means that the increase of price fairness will increase customer repurcahse intetion. When customer perceived have received more benefit than the price they paid for the food, then customer will receive higher value. Perceived higher customer value will motivate customer to purchase again the food in the future. Therefore, it is very important for the restaurant to enhance price fairness in order to increase customer repurcahse intention. This finding is line with previous reserachs that found that price fairness has significant effect to repurcahse intention (Konuk, 2019; Bo et al. 2017; Chung 2010; El Hadadat et al. 2015 and Lee 2011).

\subsubsection{Satisfaction and Repurchase Intention}

This study found that customer satisfaction has significant effect to repurchase intention. It means that the increase of customer satisfaction will increase customer repurcahse intetion. If customer satisfy to the food most probably when they need this food in the future, they will buy again the food from the same restaurant. This is so since buying the food from the new restaurant is riskier than buying the food from the existing one. In other words, satisfaction is a barrier for customer to switch to other competitor. Therefore, it is important for restaurant to enhance customer satisfaction in order to increase customer repurchase intention. This study is inline with previous reserachs that found that satisfaction has significant effect to repurchase intention (Konuk, 2019; Bo et al. 2017; Chung 2010; El Hadadat et al. 2015 and Lee 2011)

\subsection{Conclusions and Suggestions}

This study indicate that Food Quality has important role to enhance customer satisfaction and repurchase intention. In addition, Price Fairness also has significance role improve repurchase intention. However, Price Fairness does not have important role for customer satisfaction in this study. Furthermore, Customer Satisfaction has significant effect to repurchase intention. Therefore, the continous efforts of restaurant manager to improve food quality through increase food variation, food taste, food hygieness, food appearence, food texture, food colour, food nutrition and food freshness are important for enhancing customer satisfaction and repurchase intention. Furthermore, the effort of restaurant manager to improve price fairness through offering higher value of product (food) and services at reasonable price to improving customer repurchase intention.

\section{References}

Deng, Z., Lua, Y., Weib, K. K., \& Zhanga, J. (2010). Understanding customer satisfaction and loyalty: An empirical study of mobile instant messages in China. International Journal of Information Management. 88, 274-287.

Gallarza, M. G., Saura, I. G., \& Moreno, F. A. (2013). The quality-value- satisfaction-loyalty chain: relationships and impacts. Tourism Review.

Ha, J., \& Jang, S. S. (2010). Effects of service quality and food quality: The moderating role of atmospherics in an ethnic restaurant segment. International Journal of Hospitality Management. 79, 274-285.

Hair, J. F., Black, W. C., Babin, B. J., \& Andesrson, R. E. (2010). Multivariate Data Analysis Seventh Edition. England: Pearson Prentice Hall.

Hyun, S. S. (2010). Predictors of Relationship Quality and Loyalty in the Chain Restaurant Industry. Restaurant Management. International Journal of Information Management 87, 274-298.

Jalilvand, M. R., Salimipour, S., Elyasi, M., \& Mohammadi, M. (2017). Factors Influencing Word Of Mouth Behaviour In The Restaurant Industry. Marketing Intelligence \& Planning Journal of Hospitality 
Management. 79, 274-285

Kivela, J., Inbakaran, R., \& Reece, J. (1999). Consumer research in the restaurant environment, Part 1: A conceptual model of dining satisfaction and return patronage. International Journal of Contemporary Hospitality Management. 11, 894-786.

Konuk, F. A. (2019). The influence of perceived food quality, price fairness, perceived value and satisfaction on customers' revisit and word-of-mouth intentions towards organic food restaurants. Journal of Retailing and Consumer Services, 50, 103-110.

Kotler, Philip and Kevin Lane Keller. (2016). Marketing Managemen, 15th Edition, Pearson Education,Inc.

Lai, I. K. (2014). The Roles of Value, Satisfaction, and Commitment in the Effect of Service Quality on Customer Loyalty in Hong Kong-Style Tea Restaurants. Restaurant Management. Journal of Hospitality Management. 79, 274-285

Lai, J., \& Tam, M. (2011). The moderating role of perceived risk in loyalty intentions: an investigation in a service context. Marketing Intelligence \& Planning. 22, 374-277

Liang, R.-D., \& Zhang, J.-S. (2012). The effect of service interaction orientation on customer satisfaction and behavioral intention. Asia Pacific Journal of Marketing and Logistics. 257, 311-466

Liu, Y., \& Jan, S. S. (2009). Perceptions of Chinese restaurants in the U.S.: What affects customer satisfaction and behavioral intentions? International Journal of Hospitality Management. 427, 311-565

Marheni, S. (2019). Kompasiana. Dipetik Desember 13, 2018,dari kompasiana.com: http://kompasiana.com. Diakses Janjuari 2019.

Nama, J.-H., \& Leeb, T. J. (2011). Foreign travelers' satisfaction with traditional Korean restaurants. International Journal of Hospitality Management.

Peter, J. P., \& Olson, J. C. (2008). Consumer behavior and marketing strategy (8th ed.). Singapore: McGrawHill.

Qin, H., \& Prybutok, V. R. (2010). Service quality, customer satisfaction, and behavioral intentions in fast-food restaurants. International Journal of Quality and Service Sciences. 911, 634-985

Ryu, K., \& Han, H. (2009). Influence of the Quality of Food, Service, and Physical Environment on Customer Satisfaction and Behavioral Intention in Quick-Casual Restaurants: Moderating Role of Perceived Price. Journal of Hospitality \& Tourism Research. 876, 471-654

Ryua, K., Hanb, H., \& Kim, T.-H. (2008). The relationships among overall quick- casual restaurant image, perceived value, customer satisfaction, and behavioral intentions. International Journal of Hospitality Management. 8676, 112-764

Sekaran, U., \& Bougie, R. (2016). Research Methods For Business Seventh Ediotion. United Kingdom: John Wiley \& Sons Ltd.

Senic, V., \& Marinkovic, V. (2013). Patient care, satisfaction and service quality in health care. International Journal of Consumer Studies. 276, 622-332

Shahzadi,M., Malik, S. A., Ahmad, M., \& Shabbir, A. (2016). Perceptions of Fine Dining Restaurants in Pakistan: What Influences Costumer Satisfactions ang Behavioral Intentions? International Journal of Quality \& Reliability Mnagement. 576, 322-432

Sulek, J. M., \& Hensley, R. L. (2004). The Relative Importance of Food, Atmosphere, and Fairness of Wait: The Case of a Full-service Restaurant. Cornell Hotel and Restaurant Administration Quarterly 222, 442-112 